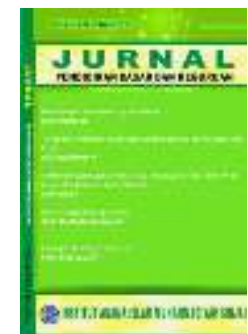

JURNAL

Pendidikan Dasar dan Keguruan

Volume 5, No. 1, 2020

ISSN (print) : 2527-578X

ISSN (Online): 2715-6818

Homepage : http://journal.iaimsinjai.ac.id/index.php/JPDK

\title{
ANALISIS KESALAHAN BERBAHASA DALAM TUGAS MAKALAH MAHASISWA PROGRAM STUDI PGMI SEMESTER III TAHUN AKADEMIK 2019/2020
}

\author{
Laeli Qadrianti ${ }^{1}, \mathbf{R i t a}^{2}$, Amran $\mathbf{A R}^{3}$ \\ ${ }^{1}$ IAI Muhammadiyah Sinjai, Sinjai \\ ${ }^{2}$ IAI Muhammadiyah Sinjai, Sinjai \\ ${ }^{3}$ IAI Muhammadiyah Sinjai, Sinjai \\ Korespondesi Penulis. E-mail: laeliqadrianti@gmail.com, Tlp:+6281354743551
}

\begin{abstract}
Abstrak
Penelitian ini bertujuan untuk mendeskripsikan bentuk kesalahan berbahasa makalah mahasiswa Program Studi Pendidikan Guru Madrasah Ibtidaiyah Semester Ganjil Tahun Akademik 2019/2020. Penelitian ini adalah penelitian deskriptif kualitatif. Sumber data diperoleh dari kesalahan berbahasa dalam tugas makalah mahasiswa. Kesalahan berbahasa yang dianalisis berupa kesalahan penggunaan ejaan. Metode pengumpulan data yang digunakan adalah metode dokumentasi. Data yang telah diperoleh kemudian dianalisis menggunakan teori Miles and Huberman yang meliputi reduksi data, display atau penyajian data, kemudian kesimpulan. Berdasarkan Hasil penelitian ini ditemukan bentuk kesalahan berbahasa makalah mahasiswa Prodi PGMI Semester III Tahun Akademik 2019/2020 yakni: kesalahan penulisan huruf yang meliputi kapital dan huruf miring. Kesalahan penulisan kata yang meliputi kesalahan penulisan kata depan, pemenggalan huruf, dan kata ganti. Kesalahan penulisan tanda baca yang meliputi tanda baca titik dan tanda baca koma.
\end{abstract}

Kata Kunci: Kesalahan berbahasa, tugas makalah.

\begin{abstract}
This study aims to describe the form of language errors in the papers of the Madrasah Ibtidaiyah Teacher Education Study Program Odd Semester Academic Year 2019/2020. This research is a descriptive qualitative research. Data source is obtained from language errors in student paper assignments. Language errors analyzed include spelling mistakes. The data collection method used is the documentation method. The data that has been obtained is then analyzed using Miles and Huberman's theory which includes data reduction, display or presentation of data, then conclusions. Based on the results of this study found the form of language errors in the papers of PGMI Study Program Semester III Academic Year 2019/2020 namely: writing errors that include capital and italics. Word writing errors that include writing prepositions, chopping letters, and pronouns. Writing punctuation errors that include period punctuation and comma punctuation.
\end{abstract}

Keywords: Language errors, paper assignments. 


\section{Pendahuluan}

Bahasa Indonesia dijadikan mata kuliah pengembang kepribadian di setiap perguruan tinggi dengan tujuan agar mahasiswa memiliki sikap popsitif terhadap bahasa Indonesia. Sikap positif terhadap bahasa Indonesia diwujudkan dengan a) kesetiaan bahasa, mendorong mahasiswa memelihara bahasa nasional; b) kebanggaan bahasa, mendorong mahasiswa mengutamakan bahasa Indonesia dan menggunakan bahasa Indonesia sebagai lambang identitas bangsa, dan c) kesadaran akan adanya norma bahasa, mendorong mahasiswa menggunakan bahasa Indonesia sesuai kaidah aturan yang berlaku. (Qadrianti, 2017: 2). Selain itu, tujuan khusus pembelajaran bahasa Indonesiadi perguruan tinggi ialah agar mahasiswa terampil menggunakan bahasa Indonesia dengan baik dan benar, secara lisan maupun tertulis sebagai sarana pengungkapan gagasan ilmiah.

Pengungkapan ide dalam bentuk kegiatan menulis merupakan salah satu bagian dari keterampilan berbahasa yangperlu mendapat perhatian lebih. Hal ini merupakan kenyataan bahwa kegiatan menulis merupakan kegiatan yang bersifat mendasar. Kegiatan menuangkan ide dalambentuk tulisan ini memerlukan pemahaman tentang kemampuan kebahasaan. Bagi pemakai bahasa khususnya mahasiswa, kegiatan menulis bukanlah suatu hal yang asing karena kegiatan ini sering dilakukan mahasiswa dalam menyelesaikan tugas-tugas perkuliahan, seperti menulis karya ilmiah dalam bentuk makalah.

Makalah merupakan karya tulis ilmiah yang dituangkan ke dalambentuk tulisan beserta penjelasannya dengan memperhatikan elemen pendukung secara ilmiah. Makalah sebagai media komunikasi yang digunakan mahasiswa untuk melatih kecerdasan, melatih keterampilan menulis, dan menanamkan kebiasaan gemar menulis. Penulisan makalah sebagai karya tulis mahasiswa dalam suatu perkuliahan agar mahasiswa kreatif dalam menulis karya tulis ilmiah. Analisis kesalahan merupakan penelaahan, penilaian sesuatu yang salah atau menyimpang dari aturan. Kesalahan dalam penggunaan Ejaan Bahasa Indonesia merupakan kesalahan dalam penggunaan atau pemakaian bahasa yang tidak sesuai dengan kaidah bahasa yang sudah disusun oleh Pusat Bahasa. (Tussolekha, 2019: $37)$.

Menurut Dulay, Burt, dan Krashen, paling sedikit ada empat landasanyang dapat digunakan dalam mengklasifikasikan kesalahan berbahasa. Keempat landasan atau yang sering dikenal dengan taksonomi itu adalah taksonomi kategori linguistik, siasat permukaan, komparatif; dan taksonomi efek komunikatif. Akan tetapi, jenis analisis kesalahan berbahasa yang digunakan dalam penelitian ini lebih didasarkan pada tinjauan dari sudut pandang linguistik (Ariningsih, 2012: 42).

Berdasarkan hasil bacaan peneliti terhadap makalah yang ditulis oleh mahasiswa Program Studi Pendidikan Guru Madrasah Ibtidaiyah Semester III Tahun Akademik 2019/2020, ditemukan banyak kesalahan penggunaan bahasa seperti penggunaan ejaan, diksi, kalimat, dan paragraf. Penggunaan ejaan yang meliputi pemakaian tanda baca, penulisan huruf, dan penulisan unsur serapan. Penggunaan diksi atau pemilihan kata yang digunakan tidak sesuai dengan konteks kalimat yang disusun. Hal ini dapat mengaburkan makna dari tulisan yang dibuat mahasiswa.Oleh karena itu, peneliti akan melakukan penelitian mengenai Analisis Kesalahan Berbahasa dalam tugas makalah mahasiswa.

Penelitian sejenis telah dilakukan seperti yang diteliti oleh Bayu Dwi Nurwicaksono (2018: 138) tentang Analisis Kesalahan Berbahasa Indonesia Pada Teks Ilmiah Mahasiswa. Temuan penelitian ini menunjukkan bahwa kesalahan berbahasa mahasiswa dalam kategori yang tinggi error $89,08 \%$, bentuk mistake $10,71 \%$, dan bentuk lapses $0,2 \%$. Temuan error pada kesalahan pemakaian huruf mencapai 183 item atau 43,16\%, temuan error pada kesalahan penulisan kata mencapai 145 item atau 34,20\%, temuan error pada pemakaian tanda baca mencapai 68 item atau 16,04\%, temuan error pada penulisan unsur serapan mencapai 28 item atau 6,6\%. Temuan-temuan tersebut membuktikan bahwa kompetensi mahasiswa Program Studi Penerbitan dalam penguasaan Ejaan Bahasa Indonesia sangat perlu ditingkatkan. 


\section{Metode}

Jenis penelitian yang digunakan pada penelitian ini adalah penelitian deskriptif kualitatif. Deskriptif kualitatif adalah suatu rancangan penelitian yang mendeskripsikan fenomena yang menjadi sasaran penelitian secara alamiah. Alamiah dimaksudkan sebagai fenomena yang menjadi sasaran penelitian dideskripsikan sebagaimana adanya. Penelitian ini dilakukan pada tugas makalah mahasiswa Program Studi Pendidikan Guru Madrasah Ibtidaiyah Semester III di Kampus IAI Muhammadiyah Sinjai, Jalan Sultan Hasanuddin No. 20 Balangnipa Kecamatan Sinjai Utara Kabupaten Sinjai.

\subsection{Sumber Data}

Sumber data dalam penelitian ini diperoleh dari makalah mahasiswa Program Studi Pendidikan Guru Madrasah Ibtidaiyah Semester Ganjil 2019/2020 mata Kuliah Media Pembelajaran.

\subsection{Metode Pengumpulan Data}

Teknik pengumpulan data adalah cara atau metode yang digunakan dalam mengumpulkan data penelitian yang terdiri atas:

a. Observasi, yaitu pengamatan dan pencatatan secara sistematik terhadap unsur-unsur yang tampak dalam suatu gejala pada objek penelitian. Dalam konteks ini, peneliti melihat dan mengamati secara langsung keadaan di lapangan (Widoyoko, 2014: 46).

b. Dokumentasi. Dilakukan dengan mengambil data-data yang mendukung penelitian atau data yang diperoleh dari makalah mahasiswa.

c. Triangulasi diartikan sebagai teknik pengumpulan data yang bersifat menggabungkan dari berbagi teknik pengumpulan data dan sumber data yang telah ada (Sugiyono, 2013: 330). Penggunaan triangulasi dalam penelitian ini untuk menguatkan informasi-informsai yang terdapat pada sumber data terkait dengan pokok persoalan yang sedang diteliti terutama yang berkenaan dengan Kesalahan penggunaan bahasa dalam makalah mahasiswa. Dalam penelitian ini peneliti melakukan triangulasi dengan perbandingan sumber dan teori, melakukan pengecekan antar data-data yang didapat dari observasi, dan dokumentasi yang ada.

\subsection{Teknik Analisis Data}

Analisis data adalah proses mencari dan menyusun secara sistematis data yang diperoleh dari dokumen dengan cara mengorganisasikan data ke dalam kategori, menjabarkan ke dalam unit-unit, melakukan sintesa, menyusun ke dalam pola, memilih mana yang penting dan yang akan dipelajari, dan membuat kesimpulan sehingga mudah dipahami oleh diri sendiri maupun orang lain (Sugiyono, 2013: 89).

Adapun metode yang peneliti gunakan dalam teknik analisis data dalam penelitian ini adalah model interaktif Miles dan Huberman yakni analisis data dilakukan saat pengumpulan data berlangsung, dan setelah pengumpulan data dalam periode tertentu (Sugiyono, 2009: 246). Hal ini dijelaskan sebagai berikut:

a. Reduksi data yaitu merangkum dan memilih hal-hal yang pokok dan fokus pada hal-hal yang penting dan mencari tema yang dianggap penting dan relevan dengan pokok penelitian yakni kesalahan penggunaan bahasa dari segi ejaan, diksi, kalimat efektif, dan paragraf.

b. Display atau penyajian data yaitu penyajian data dalam bentuk uraian singkat, bagan, dan sejenisnya yang merupakan lanjutan setelah data direduksi dan melalui penyajian data tersebut, maka data tentang kesalahan penggunaan bahasa dari segi ejaan, diksi, kalimat efektif, dan paragraf terorganisasikan, tersusun dalam pola hubungan, sehingga semakin mudah dipahami.

c. Verifikasi atau kesimpulan. Verifikasi adalah penarikan kesimpulan yakni setelah data dipolakan, difokuskan dan disusun secara sitematik dalam bentuk naratif, maka melalui metode induksi, data tersebut disimpulkan. Sehingga makna data dapat ditemukan dalam bentuk tafsiran dan argumentasi. Kesimpulan juga diverifikasi selama penelitian berlangsung. 
Volume 5, No. 1, 2020

ISSN (print) : 2527-578X

ISSN (Online): 2715-6818

Homepage : http://journal.iaimsinjai.ac.id/index.php/JPDK

\section{Hasil dan Pembahasan}

\subsection{Hasil Penelitian}

Berdasarkan analisis makalah mahasiswa ditemukan kesalahan-kesalahan berbahasa, tampak pada tabel berikut:

Tabel 1 Temuan Kesalahan-kesalahan Penulisan Huruf

\begin{tabular}{|c|c|c|c|c|}
\hline Kode & Kalimat & $\begin{array}{l}\text { Sub } \\
\text { Takso }\end{array}$ & $\begin{array}{l}\text { Jenis } \\
\text { nomi }\end{array}$ & Deskripsi \\
\hline 001a1 & $\begin{array}{l}\text { Fungsi dan Manfaat Teknologi Dan } \\
\text { Media Pembelajaran }\end{array}$ & $\begin{array}{l}\text { Kesalahan } \\
\text { Huruf } \\
\text { Kapital) }\end{array}$ & $\begin{array}{r}\text { Penulisan } \\
\text { (Huruf }\end{array}$ & $\begin{array}{l}\text { Kesalahan terdapat pada } \\
\text { penulisan kata dan yang } \\
\text { menggunakan huruf kapital. } \\
\text { Jika merujuk pada } \\
\text { Pedoman Umum Ejaan } \\
\text { Bahasa Indonesia, kata dan } \\
\text { tidak menggunakan huruf } \\
\text { kapital karen kata dan } \\
\text { merupakan konjungsi (kata } \\
\text { penghubung). }\end{array}$ \\
\hline 001a2 & $\begin{array}{lcr}\text { Latar Belakang } & \text { Penggunaan } \\
\text { Teknologi } & \text { Dan } & \text { Media } \\
\text { Pembelajaran } & & \end{array}$ & $\begin{array}{l}\text { Kesalahan } \\
\text { Huruf } \\
\text { Kapital) }\end{array}$ & $\begin{array}{r}\text { Penulisan } \\
\text { (Huruf }\end{array}$ & $\begin{array}{l}\text { Kesalahan terdapat pada } \\
\text { penulisan kata dan yang } \\
\text { menggunakan huruf kapital. } \\
\text { Jika merujuk pada } \\
\text { Pedoman Umum Ejaan } \\
\text { Bahasa Indonesia, kata dan } \\
\text { tidak menggunakan huruf } \\
\text { kapital karen kata dan } \\
\text { merupakan konjungsi (kata } \\
\text { penghubung). }\end{array}$ \\
\hline $001 \mathrm{a} 3$ & $\begin{array}{l}\text { Landasan Penggunaan Teknologi } \\
\text { Dan Media Pembelajaran }\end{array}$ & $\begin{array}{l}\text { Kesalahan } \\
\text { Huruf } \\
\text { Kapital) }\end{array}$ & $\begin{array}{r}\text { Penulisan } \\
\text { (Huruf }\end{array}$ & $\begin{array}{l}\text { Kesalahan terdapat pada } \\
\text { penulisan kata dan yang } \\
\text { menggunakan huruf kapital. } \\
\text { Jika merujuk pada } \\
\text { Pedoman Umum Ejaan } \\
\text { Bahasa Indonesia, kata dan } \\
\text { tidak menggunakan huruf } \\
\text { kapital karen kata dan } \\
\text { merupakan konjungsi (kata } \\
\text { penghubung). }\end{array}$ \\
\hline 001a4 & $\begin{array}{lrr}\text { Urgensi Teknologi dan } & \text { Media } \\
\text { Dalam Pembelajaran } & & \end{array}$ & $\begin{array}{l}\text { Kesalahan } \\
\text { Huruf } \\
\text { Kapital) }\end{array}$ & $\begin{array}{r}\text { Penulisan } \\
\text { (Huruf }\end{array}$ & $\begin{array}{l}\text { Kesalahan terdapat pada } \\
\text { penulisan kata dalam yang } \\
\text { menggunakan huruf kapital. } \\
\text { Jika merujuk pada } \\
\text { Pedoman Umum Ejaan } \\
\text { Bahasa Indonesia, kata } \\
\text { dalam tidak menggunakan } \\
\text { huruf kapital karen kata } \\
\text { dalam } \\
\text { konjungsi merupakan }\end{array}$ \\
\hline
\end{tabular}




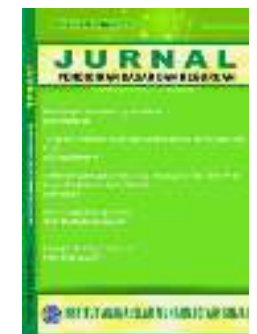

JURNAL

Pendidikan Dasar dan Keguruan

Volume 5, No. 1, 2020

ISSN (print) : 2527-578X

ISSN (Online): 2715-6818

Homepage : http://journal.iaimsinjai.ac.id/index.php/JPDK

$001 \mathrm{a} 5$

Interaksi Yang Terjalin Antara Guru dan Murid Menjadi Lebih Intens

Kesalahan Penulisan

Huruf

(Huruf

penghubung).

Kesalahan terdapat pada penulisan kata yang yang menggunakan huruf kapital. Jika merujuk pada Pedoman Umum Ejaan Bahasa Indonesia, kata yang tidak menggunakan huruf kapital karen kata yang merupakan konjungsi (kata penghubung).

001a6 Menjaga Relevansi Dengan Tujuan Kesalahan Penulisan Belajar

Huruf

(Huruf

Kapital)

Kesalahan terdapat pada penulisan kata dengan yang menggunakan huruf kapital. Jika merujuk pada Pedoman Umum Ejaan Bahasa Indonesia, kata dengan tidak menggunakan huruf kapital karen kata dengan merupakan konjungsi (kata penghubung).

001a7 Pemanfaatan dan penggunaan Kesalahan Penulisan media pembelajaran (Sub bab)

Huruf

(Huruf Kapital)

Penulisan subbab pada sebuah makalah, seharusnya setiap huruf awal kata ditulis menggunakan huruf kapital, kecuali konjungsi (dan, dengan, dll.)

001a8 Pemanfaatan Media Pembelajaran Kesalahan Penulisan (Paragraf baru)

Huruf

(Huruf

Kapital)

Penulisan kata jika menunjukkan paragraf baru, maka hanya huruf pertama kata pertama yang ditulis menggunakan huruf kapital.

001a9 Cara paktis menggunakan OHP Kesalahan Penulisan (Subjudul)

Huruf

Kapital)

(Huruf

Penulisan subbab pada sebuah makalah, seharusnya setiap huruf awal kata ditulis menggunakan huruf kapital, kecuali konjungsi (dan, dengan, dll.)

001a10 Menurut Sukorini (Warsito, 2008: Kesalahan Penulisan 215) Pusat sumber belajar...

(Huruf
Penulisan kata pusat yang ditulis menggunakan huruf kapital merupakan sebuah 


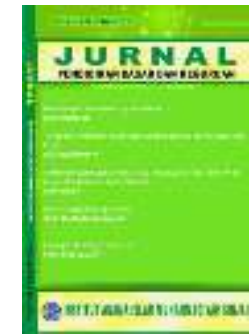

JURNAL

Pendidikan Dasar dan Keguruan

Volume 5, No. 1, 2020

ISSN (print) : 2527-578X

ISSN (Online): 2715-6818

Homepage : http://journal.iaimsinjai.ac.id/index.php/JPDK

\begin{tabular}{llll}
\hline 001 a11 & & & Kapital) \\
& $\begin{array}{l}\text { Dengan adanya Pusat sumber } \\
\text { belajar... }\end{array}$ & \\
& & $\begin{array}{l}\text { Kesalahan Penulisan } \\
\text { Huruf } \\
\text { Kapital) }\end{array}$ \\
001a12 & Prinsip-prinsip Pengelolaan PSB ... & \\
& & $\begin{array}{l}\text { Kesalahan Penulisan } \\
\text { Huruf } \\
\text { Kapital) }\end{array}$
\end{tabular}

kesalahan. Kata pusat tetap ditulis menggunakan huruf kecil karena merupakan penjelasan atau definisi.

Penulisan kata pusat yang ditulis menggunakan huruf kapital merupakan sebuah kesalahan. Kata pusat tetap ditulis menggunakan huruf kecil karena merupakan penjelasan atau definisi.

Penulisan kata pengelolaan yang ditulis menggunakan huruf kapital merupakan sebuah kesalahan. Kata pengelolaan tetap ditulis menggunakan huruf kecil karena merupakan penjelasan atau definisi.

001a13 ... bisa dilihat oleh Peserta didik di Kesalahan Penulisan kelas.

Huruf

Kapital)

(Huruf

Penulisan kata peserta yang ditulis menggunakan huruf kapital merupakan sebuah kesalahan. Huruf kapital tidak boleh ada di tengah kalimat, kecuali nama orang, Daerah, atau agama.

001a14 ... bisa menarik perhatian Peserta Kesalahan Penulisan didik dengan segera.

Huruf

Kapital)

(Huruf

Penulisan kata peserta yang ditulis menggunakan huruf kapital merupakan sebuah kesalahan. Huruf kapital tidak boleh ada di tengah kalimat, kecuali nama orang, Daerah, atau agama.

001a15 istilah asingnya recording, yaitu ... Kesalahan Penulisan Huruf (Huruf Kapital)

Kata istilah pada kalimat tersebut harusnya ditulis menggunakan huruf kapital karena berada pada awal kalimat.

001a16 Menurut Ahmad Sudrajat Sumber belajar adalah..

Kesalahan Penulisan Huruf Kapital)

(Huruf

Penulisan kata sumber harusnya ditulis dengan huruf kecil karena tidak menunjukkan nama orang, daerah, atau agama.

001a17 ... tujuan, misi, atau fungsi sumber Kesalahan Penulisan Penulisan huruf kapital 
Homepage : http://journal.iaimsinjai.ac.id/index.php/JPDK

belajar, Bentuk, format, atau Huruf keadaan fisik sumber belajar, Pesan Kapital) yang dibawa oleh sumber belajar

001a18 Semoga makalah ini bermanfaat bagi kita semua, Apabila terdapat kekurangan...

001a19 ... seperti halnya lingkungan sosial, lingkungan Alam, lingkungan Buatan...

001a20 Teknik Penggunaan Lingkungan Sebagai Media Pembelajaran

Kesalahan Penulisan Huruf Kapital)

(Huruf Huruf Kapital)

Kesalahan Penulisan Huruf Kapital)

(Huruf

Kesalahan Penulisan Huruf Kapital)

(Huruf Media Pembelajaran

$001 \mathrm{a} 2$

Faktor-Faktor

Yang

Harus

Diperhatikan

Dalam

Memilih

Teknologi

Dan

Media

Pembelajaran
Kesalahan Penulisan

Huruf

Kapital)
(Huruf

te

(enter

Setelah tanda koma (,) kata
apabila ditulis dengan
huruf kecil pada awal kata.

Penulisan huruf kapital pada kata alam dan buatan merupakan suatu kesalahan penggunaan huruf kapital. Seharusnya kata alam dan buatan ditulis menggunakan huruf kecil karena berada di tengah kalimat.

Penulisan kata sebagai menggunakan huruf kapital merupakan kesalahan penggunaan huruf kapital di tengah kalimat.

Penulisan kata dan menggunakan huruf kapital merupakan kesalahan penggunaan huruf kapital di tengah kalimat.

Penggunaan huruf kapital pada kata yang, dalam, dan dan merupakan suatu kesalahan. Kata-kata tersebut harusnya ditulis dengan huruf kecil karena kata-kata tersebut merupakan kata penghubung.

Penggunaan huruf kapital pada kata yang, dalam, dan dan merupakan suatu kesalahan. Kata-kata tersebut harusnya ditulis dengan huruf kecil karena kata-kata tersebut 


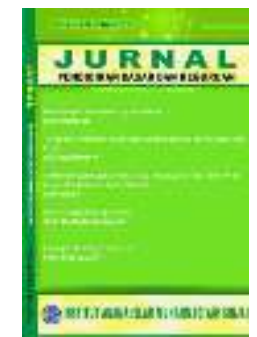

JURNAL

Pendidikan Dasar dan Keguruan

Volume 5, No. 1, 2020

ISSN (print) : 2527-578X

ISSN (Online): 2715-6818

Homepage : http://journal.iaimsinjai.ac.id/index.php/JPDK

001a24 Puji syukur kita panjatkan atas kehadirat Allah swt. Karena atas berkah dan rahmat...

001a25 oleh karena itu, kami mengucapkan terimakasih.

Kesalahan Penulisan

Huruf

Kapital)

(Huruf

Kesalahan Penulisan

Huruf

Kapital)

(Huruf

merupakan

penghubung.

Penggunaan huruf kapital pada kata karena merupakan kesalahan penggunaan ejaan. Harusnya kata karena ditulis menggunakan huruf kecil.

Pada awal kalimat harusnya menggunakan huruf kapital. Kesalahan terdapata pada kata oleh, harusnya ditulis menggunakan huruf kapital karena berada pada awal kalimat.

Kesalahan terdapat hampir pada semua penulisan kata pada kalimat tersebut. Penulisan yang tepat harusnya hanya pada awal kata menggunakan huruf kapital.

Penulisan kata dan menggunakan huruf kapital merupakan kesalahan penggunaan huruf kapital di tengah kalimat.

Huruf (Huruf Kapital)

Kesalahan penggunaan huruf kapital pada kata digital dan kata sebenarnya. Harusnya kata tersebut ditulis dengan huruf kecil.

Kesalahan penggunaan huruf kapital pada kata masjid dan kata perpustakaan gereja. Harusnya kata tersebut ditulis dengan huruf kecil.

$001 \mathrm{a} 30$ perpustakaan sebagai sumber belajar yang merupakan bagian integral yang mendukung proses belajar-mengajar.
Kesalahan Penulisan Huruf Kapital)

Kesalahan Penulisan Huruf Kapital)
(Huruf

Pada awal kalimat harusnya menggunakan huruf kapital. Kesalahan terdapata pada kata perpustakaan, 


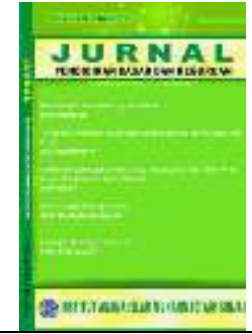

JURNAL

Pendidikan Dasar dan Keguruan

Volume 5, No. 1, 2020

ISSN (print) : 2527-578X

ISSN (Online): 2715-6818

Homepage : http://journal.iaimsinjai.ac.id/index.php/JPDK

\begin{tabular}{|c|c|c|c|c|}
\hline 001a31 & $\begin{array}{l}\text { Perpustakaan } \\
\text { Sumber Belajar }\end{array}$ & Sebagai & Pusat & $\begin{array}{lr}\text { Kesalahan } & \text { Penulisan } \\
\text { Huruf } & \text { (Huruf } \\
\text { Kapital) } & \end{array}$ \\
\hline
\end{tabular}

001a32 Perpustakaan Sebagai Pusat Kesalahan Penulisan Informasi Dan Komunikasi

Huruf

Kapital)

harusnya

ditulis

menggunakan huruf kapital

karena berada pada awal

kalimat.

Penggunaan huruf kapital pada kata sebagai termasuk satu kesalahan dalam ejaan bahasa Indonesia. Kata sebagai termasuk kata penghubung sehingga tepatnya ditulis menggunakan huruf kecil.

Penggunaan huruf kapital pada kata sebagai dan dan termasuk satu kesalahan dalam ejaan bahasa Indonesia. Kata sebagai termasuk kata penghubung sehingga tepatnya ditulis menggunakan huruf kecil.

001a33 perpustakaan merupakan pilar Kesalahan Penulisan strategis dalam mencerdaskan kehidupan bermasyarakat, berbangsa, dan bernegara.

Huruf

Kapital)

(Huruf

Pada awal kalimat harusnya menggunakan huruf kapital. Kesalahan terdapata pada kata perpustakaan, harusnya ditulis menggunakan huruf kapital karena berada pada awal kalimat.

001a34 Pengertian Perpustakaan Secara Kesalahan Penulisan etimologis, istilah perpustakaan...

Huruf

(Huruf

Kapital)

Penggunaan huruf kapital pada kata perpustakaan dan kata secara harusnya ditulis menggunakan huruf kecil.

001a35 Pentingnya media pembelajaran bagi guru di negara indonesia dan diharapkan dapat diterapkan dalam kehidupan berbangsa dan bernegara.

Kesalahan Penulisan Huruf

Kapital)

(Huruf

Kesalahan penulisan pada kata indonesia, harusnya kata indonesia menggunakan huruf kapital pada huruf pertama.

Kesalahan penulisan Huruf miring

Penulisan kata Overhead projector harusnya ditulis dengan cetak miring karena merupakan bahasa asing.

002b2 ... media komunikasi yang berua alat-alat teknologi atau disebut hardware.

Kesalahan penulisan Huruf miring

Penulisan kata Hardware harusnya ditulis dengan cetak miring karena 


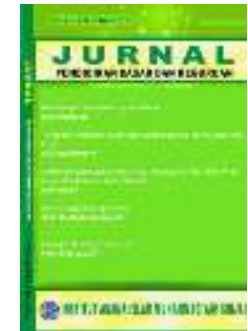

JURNAL

Pendidikan Dasar dan Keguruan

Volume 5, No. 1, 2020

ISSN (print) : 2527-578X

ISSN (Online): 2715-6818

Homepage : http://journal.iaimsinjai.ac.id/index.php/JPDK

$002 b 3$

Headphone yang tersentuh telinga atau tangan dan microphone yang tersentuh...

Kesalahan penulisan Huruf miring

merupakan bahasa asing.

Penulisan kata Headphone dan Microphone harusnya ditulis dengan cetak miring karena merupakan bahasa asing.

002b4 Menurut Association Educational Kesalahan penulisan Communication and Technology Huruf miring

$002 b 5$

Sumber belajar yang dirancang atau

Kesalahan penulisan learning resources by design, Huruf miring yakni sumber belajar yang sengaja direncanakan, ...

Penulisan singkatan

Association Educational Communication and Technology harusnya ditulis dengan cetak miring karena merupakan bahasa asing.

Penulisan kata learning resources by design harusnya ditulis dengan cetak miring karena merupakan bahasa asing.

Tabel 2 Temuan Kesalahan-kesalahan Penulisan Kata Depan

\begin{tabular}{|c|c|c|c|}
\hline Kode & Kalimat & $\begin{array}{l}\text { Sub Jenis } \\
\text { Taksonomi }\end{array}$ & Deskripsi \\
\hline $003 \mathrm{cl}$ & $\begin{array}{l}\text {.. di atas permukaan kaca yang } \\
\text { apabila lampu OHP di nyalakan } \\
\text { maka transparansi tersebut akan } \\
\text { terproyeksikan. }\end{array}$ & $\begin{array}{l}\text { Kesalahan Penulisan } \\
\text { Kata depan }\end{array}$ & $\begin{array}{lr}\text { Penulisan kata dinyalakan } \\
\text { seharusnya } & \text { ditulis } \\
\text { serangkai karena } & \text { kata } \\
\text { dinyalakan } & \text { tidak } \\
\text { menunjukkan tempat. } & \end{array}$ \\
\hline $003 c 2$ & $\begin{array}{l}\text { Simpanlah lembar-lembar } \\
\text { transparan kedalam map. }\end{array}$ & $\begin{array}{l}\text { Kesalahan Penulisan } \\
\text { Kata depan }\end{array}$ & $\begin{array}{l}\text { Penulisan kata kedalam } \\
\text { harusnya ditulis terpisah } \\
\text { karena kata ke dalam } \\
\text { menunjukkan kata tempat. }\end{array}$ \\
\hline $003 \mathrm{c} 3$ & $\begin{array}{l}\text { Film yang diputar didepan siswa } \\
\text { harus... }\end{array}$ & $\begin{array}{l}\text { Kesalahan Penulisan } \\
\text { Kata depan }\end{array}$ & $\begin{array}{l}\text { Penulisan kata didepan } \\
\text { harusnya ditulis terpisah } \\
\text { karena kata di depan } \\
\text { menunjukkan kata tempat. }\end{array}$ \\
\hline $003 c 4$ & $\begin{array}{l}\text { Di tempatkan yang jauh dari } \\
\text { bahan-bahan yang mengandung } \\
\text { magnet. }\end{array}$ & $\begin{array}{l}\text { Kesalahan Penulisan } \\
\text { Kata depan }\end{array}$ & $\begin{array}{l}\text { Penulisan kata di } \\
\text { tempatkan seharusnya } \\
\text { ditulis serangkai karena } \\
\text { kata ditempatkan tidak } \\
\text { menunjukkan tempat. }\end{array}$ \\
\hline $003 c 5$ & ... di pajang di publik. & Kesalahan Penulisan & kata dipajang \\
\hline
\end{tabular}




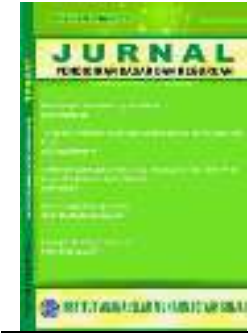

JURNAL

Pendidikan Dasar dan Keguruan

Volume 5, No. 1, 2020

ISSN (print) : 2527-578X

ISSN (Online): 2715-6818

Homepage : http://journal.iaimsinjai.ac.id/index.php/JPDK

$003 c 6$

$003 \mathrm{c} 7$

$003 \mathrm{c} 8$

$003 \mathrm{c} 9$

$003 \mathrm{c} 10$

003c11 ... siswa memperoleh pengalaman langsung sebagai ilmu yang diaplikasikannya dari teori ke penerapan

003c12 Lingkungan adalah sesuatu gejala alam yang ada disekitar kita, dimana terdapat interaksi antara faktor biotik dan abiotik.

003c13 Lingkungan yang berada disekitar kita dapat dijadikan...

003c14 Siswa juga lebih dapat memahami dan menghayati aspek-aspek kehidupan yang ada dilingkungannya.

003c15 Banyak guru yang masih berpandangan sempit bahwa belajar hanya dilakukan didalam kelas.

003c16 Mereka dapat lebih mudah menerima dan memahami materi pembelajaran dengan bantuan media pembelajaran yang sudah dipilih sesuai kriteria diatas.
Kata depan

Kesalahan Penulisan

Kata depan

Kesalahan Penulisan

Kata depan

Kesalahan Penulisan

Kata depan

Kesalahan Penulisan

Kata depan

Kesalahan Penulisan

Kata depan

Kesalahan Penulisan

Kata depan

Kesalahan Penulisan Kata depan

Kesalahan Penulisan Kata depan

Kesalahan Penulisan Kata depan

Kesalahan Penulisan Kata depan

Kesalahan Penulisan Kata depan

harusnya ditulis serangkai.

Penulisan kata dilaminasi harusnya ditulis serangkai.

Penulisan kata di antara harusnya ditulis terpisah antara di dan antara.

Penulisan

kata dimanfaatkan harusnya ditulis serangkai.

Penulisan kata diolah harusnya ditulis serangkai.

Penulisan kata diobservasi harusnya ditulis serangkai.

Penulisan kata kepenerapan harusnya ditulis serangkai.

Penulisan kata di sekitar harusnya ditulis terpisah karena menunjukkan kata tempat. Demikian dengan kata di mana.

Penulisan kata di sekitar harusnya ditulis terpisah karena menunjukkan kata tempat.

Penulisan kata di lingkungannya harusnya ditulis terpisah karena menunjukkan kata tempat.

Penulisan kata di dalam harusnya ditulis terpisah karena menunjukkan kata tempat.

Penulisan kata di atas harusnya ditulis terpisah karena menunjukkan kata tempat.

Penulisan kata di atas harusnya ditulis terpisah 


\begin{tabular}{|c|c|c|c|}
\hline 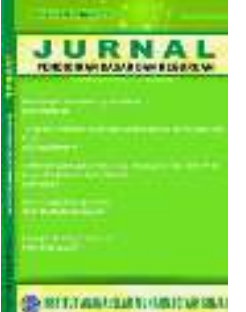 & \multicolumn{3}{|c|}{$\begin{array}{l}\text { JURNAL } \\
\text { Pendidikan Dasar dan Keguruan } \\
\text { Volume 5, No. 1, 2020 } \\
\text { ISSN (print) : 2527-578X } \\
\text { ISSN (Online): 2715-6818 } \\
\text { Homepage : http://journal.iaimsinjai.ac.id/index.php/JPDK }\end{array}$} \\
\hline & disimpulkan... & Kata depan & $\begin{array}{l}\text { karena menunjukkan kata } \\
\text { tempat. }\end{array}$ \\
\hline $003 \mathrm{c} 18$ & $\begin{array}{llr}\text { Disamping } & \text { itu, juga } \\
\text { memungkinkan pengajar untuk } \\
\text { mengembangkan pengetahuan } \\
\text { secara mandiri, dan juga dapat } \\
\text { mengajar dengan metode bervariasi. }\end{array}$ & $\begin{array}{l}\text { Kesalahan Penulisan } \\
\text { Kata depan }\end{array}$ & $\begin{array}{l}\text { Penulisan kata di samping } \\
\text { harusnya ditulis terpisah } \\
\text { karena menunjukkan kata } \\
\text { tempat. }\end{array}$ \\
\hline $003 \mathrm{c} 19$ & $\begin{array}{l}\text { Suatu objek yang sudah di ambil } \\
\text { gambarnya dengan kamera atau } \\
\text { video kamera dapat di produksi } \\
\text { denga mudah kapan saja di } \\
\text { perlukan. }\end{array}$ & $\begin{array}{l}\text { Kesalahan Penulisan } \\
\text { Kata depan }\end{array}$ & $\begin{array}{l}\text { Penulisan kata diambil, } \\
\text { diproduksi, diperlukan } \\
\text { harusnya ditulis serangkai. }\end{array}$ \\
\hline $003 c 20$ & $\begin{array}{l}\text {... objek yang telah di rekam atau } \\
\text { di simpan dengan format media } \\
\text { yang ada dapat di gunakan setiap } \\
\text { saat. }\end{array}$ & $\begin{array}{l}\text { Kesalahan Penulisan } \\
\text { Kata depan }\end{array}$ & $\begin{array}{l}\text { Penulisan kata di rekam, di } \\
\text { simpani, di gunakan } \\
\text { harusnya ditulis serangkai. }\end{array}$ \\
\hline $003 \mathrm{c} 21$ & $\begin{array}{l}\text { Peristiwa yang kejadiannya hanya } \\
\text { sekali dapat di abadikan dan di } \\
\text { susun kembali untuk keperluan } \\
\text { pembelajaran. }\end{array}$ & $\begin{array}{l}\text { Kesalahan Penulisan } \\
\text { Kata depan }\end{array}$ & $\begin{array}{l}\text { Penulisan kata di abadikan, } \\
\text { di susun harusnya ditulis } \\
\text { serangkai. }\end{array}$ \\
\hline $003 c 22$ & $\begin{array}{l}\text {... kegiatan siswa dapat di rekam } \\
\text { untuk kemudian di analisis dan di } \\
\text { kritik. }\end{array}$ & $\begin{array}{l}\text { Kesalahan Penulisan } \\
\text { Kata depan }\end{array}$ & $\begin{array}{l}\text { Penulisan kata di rekam, di } \\
\text { analisis, di kritik harusnya } \\
\text { ditulis serangkai. }\end{array}$ \\
\hline $004 d 1$ & ... ketram-pilan dasar mengajar. & & $\begin{array}{lr}\text { Penulisan yang tepat untuk } \\
\text { pemenggalan } & \text { kata } \\
\text { keterampilan yakni ke- } \\
\text { terampil-an. }\end{array}$ \\
\hline $004 d 2$ & $\begin{array}{l}\ldots \text { sehingga lebih nyata, lebih } \\
\text { faktual, dan kebenarannya dapat } \\
\text { dipertanggung jawabkan. }\end{array}$ & Pemenggalan kata & $\begin{array}{lr}\text { Penulisan } & \text { kata } \\
\text { dipertanggung jawabkan, } \\
\text { harusnya ditulis } \\
\text { dipertanggungjawabkan. }\end{array}$ \\
\hline $004 d 3$ & $\begin{array}{l}\text { oleh karena itu, kami mengucapkan } \\
\text { terimakasih. }\end{array}$ & & $\begin{array}{l}\text { Penulisan kata terimakasih } \\
\text { harusnya dipisah menjadi } \\
\text { terima kasih. }\end{array}$ \\
\hline $005 \mathrm{e} 1$ & $\begin{array}{l}\ldots \text { media apa yang ia gunakan untuk } \\
\text { belajar. }\end{array}$ & $\begin{array}{l}\text { Kesalahan } \\
\text { penggunaan kata } \\
\text { ganti }\end{array}$ & $\begin{array}{l}\text { Penggunaan kata ganti ia } \\
\text { kurang tepat, harusnya } \\
\text { menggunakan kata peserta } \\
\text { didik atau siswa. }\end{array}$ \\
\hline
\end{tabular}




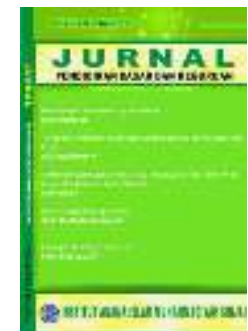

JURNAL

Pendidikan Dasar dan Keguruan

Volume 5, No. 1, 2020

ISSN (print) : 2527-578X

ISSN (Online): 2715-6818

Homepage : http://journal.iaimsinjai.ac.id/index.php/JPDK

Tabel 3 Temuan Kesalahan-kesalahan Penulisan Tanda Baca

\begin{tabular}{|c|c|c|c|}
\hline Kode & Kalimat & $\begin{array}{l}\text { Sub Jenis } \\
\text { Taksonomi }\end{array}$ & Deskripsi \\
\hline $006 f 1$ & $\begin{array}{l}\text { Oleh karena itu pembelajaran } \\
\text { mikro... }\end{array}$ & $\begin{array}{l}\text { Kesalahan Penulisan } \\
\text { Tanda Baca }\end{array}$ & $\begin{array}{l}\text { Setelah kata itu harusnya } \\
\text { menggunakan tanda baca } \\
\text { koma. }\end{array}$ \\
\hline $006 f 2$ & $\begin{array}{l}\text { Oleh karena itu dalam rangka } \\
\text { penguasaan... }\end{array}$ & $\begin{array}{l}\text { Kesalahan Penulisan } \\
\text { Tanda Baca }\end{array}$ & $\begin{array}{l}\text { Setelah kata itu harusnya } \\
\text { menggunakan tanda baca } \\
\text { koma. }\end{array}$ \\
\hline $006 f 3$ & Suara, objek dan gambar & $\begin{array}{l}\text { Kesalahan Penulisan } \\
\text { Tanda Baca }\end{array}$ & $\begin{array}{l}\text { Setelah kata objek harusnya } \\
\text { menggunakan tanda baca } \\
\text { koma. }\end{array}$ \\
\hline 006f 4 & $\begin{array}{l}\text { Menurut } \quad \text { Milburga, dkk, } \\
\text { perpustakaan } \\
\text { unit kerja dari sebolah ialah suah lembaga... }\end{array}$ & $\begin{array}{l}\text { Kesalahan Penulisan } \\
\text { Tanda Baca }\end{array}$ & $\begin{array}{ll}\text { Penulisan singkatan } d k k \text {, } \\
\text { yang tepat harusnya } \\
\text { menggunakan tanda baca } \\
\text { titik sebagai tanda } \\
\text { singkatan sebelum tanda } \\
\text { baca koma. }\end{array}$ \\
\hline $006 f 5$ & $\begin{array}{l}\text { Oleh karena itu perpustakaan } \\
\text { digital ada yang menyebut... }\end{array}$ & $\begin{array}{l}\text { Kesalahan Penulisan } \\
\text { Tanda Baca }\end{array}$ & $\begin{array}{l}\text { Setelah kata itu harusnya } \\
\text { menggunakan tanda baca } \\
\text { koma. }\end{array}$ \\
\hline $006 f 6$ & $\begin{array}{l}\text { Misalnya perpustakaan Masjid, } \\
\text { Perpustakaan Gereja, dan lainlain. }\end{array}$ & $\begin{array}{l}\text { Kesalahan Penulisan } \\
\text { Tanda Baca }\end{array}$ & $\begin{array}{l}\text { Kesalahan penulisan kata } \\
\text { lainlain. } \\
\text { menggunakan tanda baca } \\
\text { penghubung menjadi lain- } \\
\text { lain. }\end{array}$ \\
\hline 006f7 & $\begin{array}{l}\text {... seperti layanan media, pelatihan, } \\
\text { konsultasi pembelajaran, dll) }\end{array}$ & $\begin{array}{l}\text { Kesalahan Penulisan } \\
\text { Tanda Baca }\end{array}$ & $\begin{array}{l}\text { Penulisan singkatan dll, } \\
\text { yang tepat harusnaa } \\
\text { menggunakan tanda baca } \\
\text { titik sebagai tanda } \\
\text { singkatan sebelum tanda } \\
\text { baca koma. }\end{array}$ \\
\hline
\end{tabular}

\subsection{Pembahasan}

a. Analisis Kesalahan Penulisan Huruf

Kesalahan penulisan huruf yang ditemukan dalam makalah mahasiswa Program Studi Pendidikan Guru Madrasah Ibtidaiyah (PGMI) tahun akademik 2019/2020, yakni kesalahan penggunaan huruf kapital dan kesalahan penggunaan huruf miring. Rata-rata kesalahan mahasiswa dalam menulis huruf kapital yakni menempatkan huruf kapital di tengah kalimat yang seharusnya huruf kapital tidak boleh ditempatkan di tengah kalimat jika bukan untuk menuliskan nama orang, 


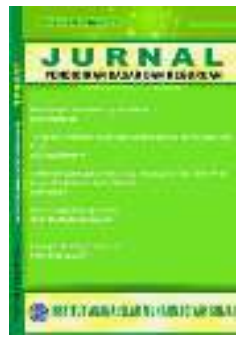

JURNAL

Pendidikan Dasar dan Keguruan

Volume 5, No. 1, 2020

ISSN (print) : 2527-578X

ISSN (Online): 2715-6818

Homepage : http://journal.iaimsinjai.ac.id/index.php/JPDK

nama negara, atau nama agama. Adapun kode yang digunakan untuk kesalahan penulisan huruf kapital dalam penelitian ini yakni 001a1-n.

Kesalahan penggunaan huruf miring tampak pada penulisan istilah-istilah asing yang tidak diceta dengan huruf miring, harusnya istilah-istilah asing tersebut harus dicetak miring. Kode yang digunakan untuk kesalahan penulisan huruf miring yakni 001b1-n.

b. Analisis Kesalahan Penulisan Kata

Kesalahan penulisan kata yang ditemukan dalam makalah mahasiswa Program Studi Pendidikan Guru Madrasah Ibtidaiyah (PGMI) tahun akademik 2019/2020, yakni kesalahan yang penulisan kata depan, kata ganti, dan pemenggalan kata. Kesalahan penulisan kata depan yang dilakukan oleh mahasiswa seperti penulisan kata didalam, seharusnya penulisan kata di dalam penulisannya tidak dirangkai karena kata di dalam menunjukkan kata tempat. Kode yang digunakan untuk kesalahan penulisan kata depan 003c1-n.

Kesalahan penulisan kata ganti yang ditemukan dalam makalah mahasiswa prodi PGMI, yakni penggunaan kata $i a$ dalam kalimat, harusnya kata ia diganti menjadi peserta didik. Kode untuk kesalahan penulisan kata ganti dalam penelitian ini yakni 005e1.

Kesalahan lain yang ditemukan dalam makalah mahasiswa prodi PGMI, yakni kesalahan pemenggalan kata. Kesalahan pemenggalan kata dapat mengubah makna kata serta menyebabkan kesalahan pembentukan kata dalam ilmu morfologi. Kode yang digunakan untuk kesalahan pemenggalan kata dalam penelitian ini yakni 001d1-n.

c. Analisis Kesalahan Penggunaan Tanda Baca

Kesalahan penggunaan tanda baca yang ditemukan dalam makalah mahasiswa Program Studi Pendidikan Guru Madrasah Ibtidaiyah (PGMI) tahun akademik 2019/2020, yakni kesalahan penggunaan tanda baca titik dan tanda baca koma. Kesalahan penggunaan tanda baca koma banyak ditemukan pada penulisan oleh karena itu. Harusnya setelah oleh karena itu dibubuhi tanda baca koma. Kode yang digunakan untuk kesalahan penggunaan tanda baca titik dan koma, yakni 006f1-n.

\section{Simpulan}

Berdasarkan analisis dan pembahasan hasil penelitian pada BAB IV ditemukan bentuk kesalahan berbahasa makalah mahasiswa Prodi PGMI Semester III Tahun Akademik 2019/2020 yakni: kesalahan penulisan huruf yang meliputi kapital dan huruf miring. Kesalahan penulisan kata yang meliputi kesalahan penulisan kata depan, pemenggalan huruf, dan kata ganti. Kesalahan penulisan tanda baca yang meliputi tanda baca titik dan tanda baca koma.

\section{Ucapan Terima kasih}

Ucapan terima kasih kepada pimpinan IAI Muhammadiyah Sinjai yang telah memberikan dukungan dana untuk melaksanakan penelitian tahun akademik 2019/2020.

\section{Daftar Pustaka}

Ariningsih, Nur Endah. (2012). "Sumarwati, Kundharu Saddhono, Analisis Kesalahan Berbahasa Indonesiadalam Karangan EksposisiSiswa Sekolah Menengah Atas", BASASTRA Jurnal Penelitian Bahasa, Sastra Indonesia dan Pengajarannya, Vol. 1 No. 1, Universitas Sebelas Maret.

Tim Pengembang Pedoman Bahasa Indonesia. (2016). Pedoman Umum Ejaan Bahasa Indonesia. Jakarta: Badan Pengembangan dan Pembinaan Bahasa.

Junus, Andi Muhammad dan Andi Muhammad Fatimah Junus. (2017). Analisis Kesalahan Berbahasa, Makassar: Badan Penerbit UNM.

Nurwicaksono, Bayu Dwi dan Diah Amelia. (2018). "Analisis Kesalahan Berbahasa Indonesia Pada Teks Ilmiah Mahasiswa", AKSIS Jurnal Pendidikan Bahasa dan Sastra Indonesia Volume 2 Nomor 2, Politeknik Negeri Media Kreatif.

Oktaviani, Feny., Muhammad Rohmadi., Purwadi, (2018). Analisis Kesalahan Berbahasa Indonesia Pada Karangan Eksposisi Siswa Kelas X MIPA (Studi Kasus Di SMA Negeri 4 
Volume 5, No. 1, 2020

ISSN (print) : 2527-578X

ISSN (Online): 2715-6818

Homepage : http://journal.iaimsinjai.ac.id/index.php/JPDK

Surakarta),BASASTRA Jurnal Penelitian Bahasa, Sastra Indonesia dan Pengajarannya, Volume 6 Nomor 1, Universitas Sebelas Maret.

Qadrianti, Laeli. (2017). Pembinaan Bahasa Indonesia, Sinjai: CV Latinulu.

S. Eko Putro Widoyoko. (2014). Teknik Penyusunan Instrumen Penelitian, Yogyakarta: Pustaka Pelajar.

Sugiyono. (2013). Memahami Penelitian Kualitatif, Bandung: Alfabeta.

Sugiyono. (2009). Metode Penelitian Kuantitatif, Kualitatif dan R\&D, Bandung: Alfabeta.

Tussolekha, Rohmah. (2019). "Kesalahan Penggunaan Ejaan Bahasa Indonesia pada Makalah Karya Mahasiswa", Aksara Jurnal Bahasa dan Sastra, Vol. 20 No. 1, STKIP Muhammadiyah Pringsewu Lampung. 